\title{
PENGARUH KUALITAS HARGA LAYANAN DAN KEPUASAN TERHADAP KESETIAAN USIA MILLENIAL BERKUNJUNG KE TEMPAT WISATA
}

Stella Alvianna ${ }^{1}$ dan Syarif Hidayatullah ${ }^{2}$

${ }^{1,2}$ Universitas Merdeka, Malang, Indonesia, email: stellaalvianna3@gmail.com

\begin{abstract}
ABSTRAK
Histori Artikel

Submitted:

24 Februari 2020

Reviewed:

1 Maret 2020

Accepted:

20 Maret 2020

Published:

15 Mei 2020

Tujuan dari penelitian untuk menganalisis variabel pengaruh kualitas produk, harga dan kualitas informasi terhadap kesetiaan pelanggan dengan variabel kepuasan pelanggan sebagai mediator variabel pada destinasi wisata Taman Wisata Wendit . Populasi penelitian ini menggunakan semua mahasiswa Program Diploma Kepariwisataan yang berusia antara 15-34 tahun dengan sampel berjumlah 75 orang mahasiswa. Hasil dari penelitian menunjukan Kualitas dari produk tidak berpengaruh langsung pada kepuasan dari pelanggan wisata Wendit, harga dan kualitas layanan berpengaruh secara langsung terhadap kepuasan pelanggan, Kualitas produk berpengaruh langsung terhadap kesetiaan pelanggan wisata Wendit, harga tidak berpengaruh secara langsung terhadap kesetiaan pelanggan wisata Wendit, Kualitas layanan tidak berpengaruh langsung pada kesetiaan pelanggan wisata Wendit serta Kualitas produk berpengaruh secara tidak langsung terhadap kesetiaan pelanggan tempat wisata Wendit melalui kepuasan dari pelanggan.
\end{abstract}

Kata Kunci : kepuasan dan loyalitas pelanggan, Usia Millenial

\section{THE EFFECT OF QUALITY PRICE QUALITY OF SERVICE AND SATISFACTION ON LOYALTY OF MILLENAL AGES VISIT TO TOURISM}

\begin{abstract}
This study focuses on analyzing the effeect of product quality, price and quality of information on customerr loyalty with customerr satisfaction as a mediator variable toward the tourist destinations of Wendit Tourism Park. All tourism Diploma Program students aged 15-34 years were the population in this study which 75 respondents were taken as a sample. The results revealed the quality of the product had no effect directly the sattisfaction of the customerrs of Wendit tourism, while the price affected directly the satisfaction of the customers of Wendit tourism, the quality of service directly affected the satisfaction of the customers of Wendit tourism, the quality of the product dirrectly affected the looyalty of Wendit tourism customers, the price had no effect Wendit tourism customer loyalty directly, the quality of service had no effect the loyalty of Wendit tourism customers directly and product quality indirectly affected the loyalty of Wendit tourism customers through customer satisfaction.
\end{abstract}

Keywords : Customer Satisfaction and Loyalty, Millennial Generation 


\section{PENDAHULUAN}

Kesetiaan pelanggan menjadi salah satu kunci keberhasilan atau keberlanjutan suatu destinasi, faktor lain yang mempengaruhi kesetiaan pelanggan adalah kepuasan pelanggan, hal ini mempunyai keterkaitan yang cukup kuat. Kesetiaan pelanggan akan timbul apabila pelanggan merasa puas dengan layanan, produk termasuk juga harga yang ditawarkan.

Selanjutnya kesetiaan pelanggan dapat juga dikatakan sebagai loyalitas pelanggan. Loyalitas dari pelanggan merupakan orang yang melakukan pembelian, khususnya pelanggan yang melakukan pembelian secara teratur dan berulang-ulang, loyalitas pelanggan dapat terjadi apabila pelanggan merasa puas dan mau untuk ikut mengajak orang lain untuk berkunjung (Hasan \& Putra, 2019).

Beberapa faktor yang dapat mempengaruhi kepuasan pelaanggan, merupakan adanya perasaan yang senang dan atau kecewa seseorang yang muncul setelah pelanggan tersebut membandingkan dengan kesannya terhadap kinerja dari suatu produk dan harapan yang pelanggan inginkan, pelanggan dapat dikatakan puas apabila kesan yang diharapkan melebihi hasil yang diterima (Kotler, 2012)

Sedangkan kualitas produk merupakan pengukuran terhadap jasa yang telah ditawrkan oleh pengelola. Kualitas dari suatu produk dapat diartikan sebagai evaluasi dari pelanggan dari hasil kinerja barang ataupun jasa, kualitas produk, besaran harga yang ditawarkan, dan kualitas dari layanan yang diberikan pada setiap pelanggan, dalam penelitian ini pelanggan yang dimaksudkan adalah generasi milenial (Aryani \& Rosinta, 2010; Alvianna, 2017)..

Pariwisata telah menjadi kebutuhan sekunder, dimana setiap orang pasti membutuhkan wisata untuk menghilangkan kejenuhan setelah bekerja atau beraktivitas lainnya. Pemilihan destinasi wisata generasi milenial juga berbeda. Kecenderungan memilih detinasi wisata yang instagramable lebih diminati disbanding yang lain.

Artikel ini mengangkat Taman Wisata Air Wendit, mengingat destinasi wisata ini bukan menjadi pilihan bagi generasi milenial. Penelitian sebelumnya yang menjadi rujukan dalam artikel ini adalah artikel yang dikemukakan oleh Hermawan, Wijayanti, \& Nugroho, (2019) bahwa loyalitas pada ekowisata dapat ditentukan oleh faktor daya tarik wisata, keamanan, dan fasilitas, dengan kepuasan sebagai variabel intervening.

Pendapat lain yang disampaikan oleh Hidayatullah, Rachmawati, Aristanto, Waris, \& Patalo, (2020), loyalitas berkunjung ke tempat wisata untuk generasi millennial sangat tergantung pada sistem informasi pemasaran, kualitas pelayanan, dan entrepreneurial marketing dari pengelola tempat wisata.

Selanjutnya artikel lain yang disampaikan oleh Hermawan (2016) mengatakan bahwa pariwisata sangat penting dampaknya untuk perkembangan ekonomi masyarakat lokal. Selanjutnya harga juga sangat menentukan minat berkunjung wisatawan.

Atas dasar tersebut, kelestarian Destinasi wisata Wendit yang ada di Kota Malang sangat diperlukan untuk dilakukan kajian dalam rangka mempertahankan eksistensi wisata dan keberadaan Wisata Wendit dalam menghadapi persaingan wisata modern. Terlebih, bagi generasi milenia yang dilihat dari kualitas produk, harga, kualitas layanan dan kepuasan terhadap loyalitas wisatawan. Serta kemungkinan diperlukannya wisata tematik seperti yang disampaikan oleh Damasdino (2015) dalam artikelnya studi karakteristik wisatawan dan upaya pengembangan produk wisata tematik di Pantai Goa Cemara, Pantai Kuwaru, dan Pantai Pandansimo Baru Kabupaten Bantul.

Tujuan yang ingin dicapai dalam Artikel ini adalah mengetahui serta menganalisis pengaruh kualitas suatu produk, harga dan kualitas layanan terhadap loyalitas pelanggan dengan menggunakan kepuasan pelanggan sebagai variable mediator. 


\section{LITERATUR REVIEW}

\section{Generasi Milenial}

Generasi millenial (Millennial Generation) merupakan orang yang terlahir dalam pada awal tahun 1980an sampai dengan tahun 2000 (Yuswohady, 2016). Sebutan lain dari generasi milenial adalah Net Generation, Gen-Y, Boomerang Generation,Generatiion WE, Peter of Pan Generation, dan masih banyak sebuatan lain untuk generasi ini. Mereka dapat dikatakan sebagai generasi millenial disebabkan mereka adalah generasi terlahir pada saat pergantian tahun millenium. Pada era tersebut era untuk teknologi serba digital sudah berkembang dan sudah mulai masuk pada semua aspek dalam kehidupan dalam masyarakat.

Dari penelitian Nurhasan (2017) generasi Y dapat dikenal pula dengan generasi millenial dan atau milenium. Sebutan untuk generasi Y sudah mulai digunakan pada terbitan Koran media besar di Amerika serikat sekitar bulan Agustus tahun 1993.

Usia Millenial ini lebih banyak menggunakan teknologi dalam berkomunikasi dan pesan instan seperti e-mail, pesan singkat (SMS), serta media sosial, antara lain: face book, Instagram, serta twitter dan media social lain yang bersifat online, sehingga generasi tipe $\mathrm{Y}$ merupakan generasi muncul bersamaan dengan saat masa internet berkembang. Berdasarkan pada informasi tersebut, bisa disimpulkan tentang generasi millenial atau generasi Y merupakan generasi yang terlahir pada tahun 1980 - 2000, pada saat adanya kemajuan dan perkembangan teknologi. Jika ditlihat dari kelompok usia, generasi ini (milenial) merupakan mereka yang pada tahun ini (2020) memiliki usia diantara 15 34 tahun.

\section{METODE}

Pendekatan penelitian yang telah digunakan adalah dengan deskriptif kuantitaif, yaitu jenis penelitian dengan menekankan analisis numerik. Adapun explanatory research merupakan jenis penilitian yang digunakan untuk menjelaskan hubungan kausal dari variabel penelitian dengan hipotesa yang sudah dirumuskan, sehingga dapat diketahui seberapa besar kontribusi suatu variabel Bebas terhadap variabel Terikat (sugiyono, 2014).

Penelitian telah dilakukan dengan menggunakan variabel bebas: kualitas produk (X1), harga (x2) dan kualitas layanan (X3), variebel terikat kesetiaan pelanggan atau loyalitas (Y2) dan variabel moderating kepuasan pelanggan (Y1).

Lokasi penelitian di Program Diploma Kepariwisataan Universitas Merdeka Malang. Populasi penelitian adalah semua mahasiswa yanng pernah berwisata ke tempat Wisata Wendit, sedangkan jumlah sampel dalam sejumlah 75 orang. Kriteria sampel adalah mahasiswa yang berusia antara 15-34 tahun dan pernah berkunjung ke Wisata Wendit.

Data primer maupun data sekunder merupakan sumber data yang digunakan. Adapun untuk menjelaskan analisis jalur path digunakan analisis regresi linear berganda 2 (dua) model. Sedangkan model kerangka konsep penelitian dari penelitian sebagai berikut :

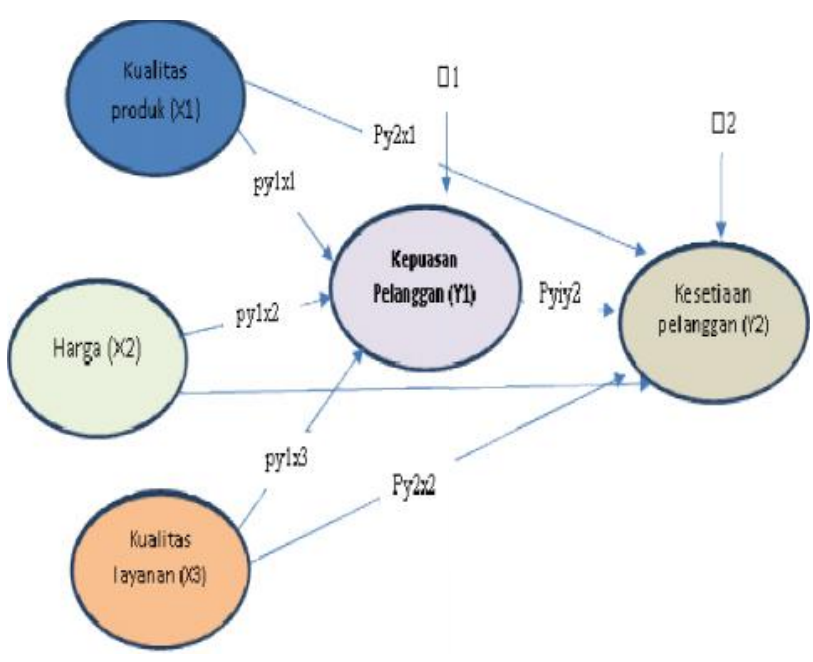

Gambar 1 : Kerangka Konseptual Penelitian 


\section{HASIL DAN PEMBAHASAN}

\section{Karakteristik Responden dan Hasil Satatistik Deskripstif}

Diketahui kondisi dari responden yang ada pada penelitian ini mayoritas laki -laki yaitu sebesar 43 orang, sedangkan responden perempuan ada 32 orang. Sedangkan sebaran responden ada sejumlah 14 orang dari D3 Perjalanan Wisata, 23 orang dari D3 Perhotelan dan yang terbesar sejumlah 38 orang dari D4 Destinasi Wisata.

Selanjutnya mayoritas responden berkunjung pertama kali atau satu kali ke tempat Wisata Wendit sebanyak 38 orang, yang pernah ke wisata Wendit dua kali sejumlah 23 orang, yang pernah berkunjung tiga kali sejumlah 11 orang dan yang berwisata lebih dari tiga kali sejumlah 3 orang.

\section{Analisis Model Regresi}

Hasil dari analisis regresi pada Model I di ketahui nilai signifikan dari ketiga variabel, $\mathrm{X} 2=0,000, \mathrm{X} 3=0,008$ lebih keci dari 0,05 . Hal ini memberikan suatu kesimpulan dari regresi model I yakni Variabel X2 dan X3 dikatakan signifikan terhadap Y. Sedangkan variable $\mathrm{X} 1=0,190$ dimana $0,190>0,05$ menandakan variable $\mathrm{X} 1$ tidak memiliki pengaruh signifikan terhadap variabel Y.

Besarnya dari nilai $\mathrm{R} 2$ atau $\mathrm{R}$ square pada tabel Model sumary adalah 0,935, menunjukan bahwa kontribusii atau sumbangan pengaruh $\mathrm{X}_{1}, \mathrm{X}_{2}$ dan $\mathrm{X}_{3}$ terhadap variabel $\mathrm{Y}$ sebesar 93,5\%, sementara selisihnya sebesar $6,5 \%$ adalah Kontribusi variabel -variabel yang tidak dimasukan dalam variabel penelitian ini. sedangkannilai e1 $=\sqrt{ }(1-0,935)=$ $\sqrt{ }(0,065)=0,255$

Menguji hipotesis dalam penelitian ini dengan melihat hasil $\mathrm{F}$ hitung 337,762 atau melihat dari nilai signifikan 0,000 , hal ini artinya $0,000<0,05$ maka $\mathrm{H}_{\mathrm{o}}$ ditolak serta $\mathrm{H}_{1}$ diterima yang berarti terdapat hubungan kualitas produk, harga dan kualitas pelayanan terhadap kepuasan pengunjung.

\section{Uji Hipotesis}

Ada 10 hipotesis yang diuji dalam artikel ini, dan hipotesis yang ada dibagi dalam pengaruh secara langsung dari masingmasing variabel, pengaruh tidak langsung (melalui variabel antara) serta pengaruh total variabel.

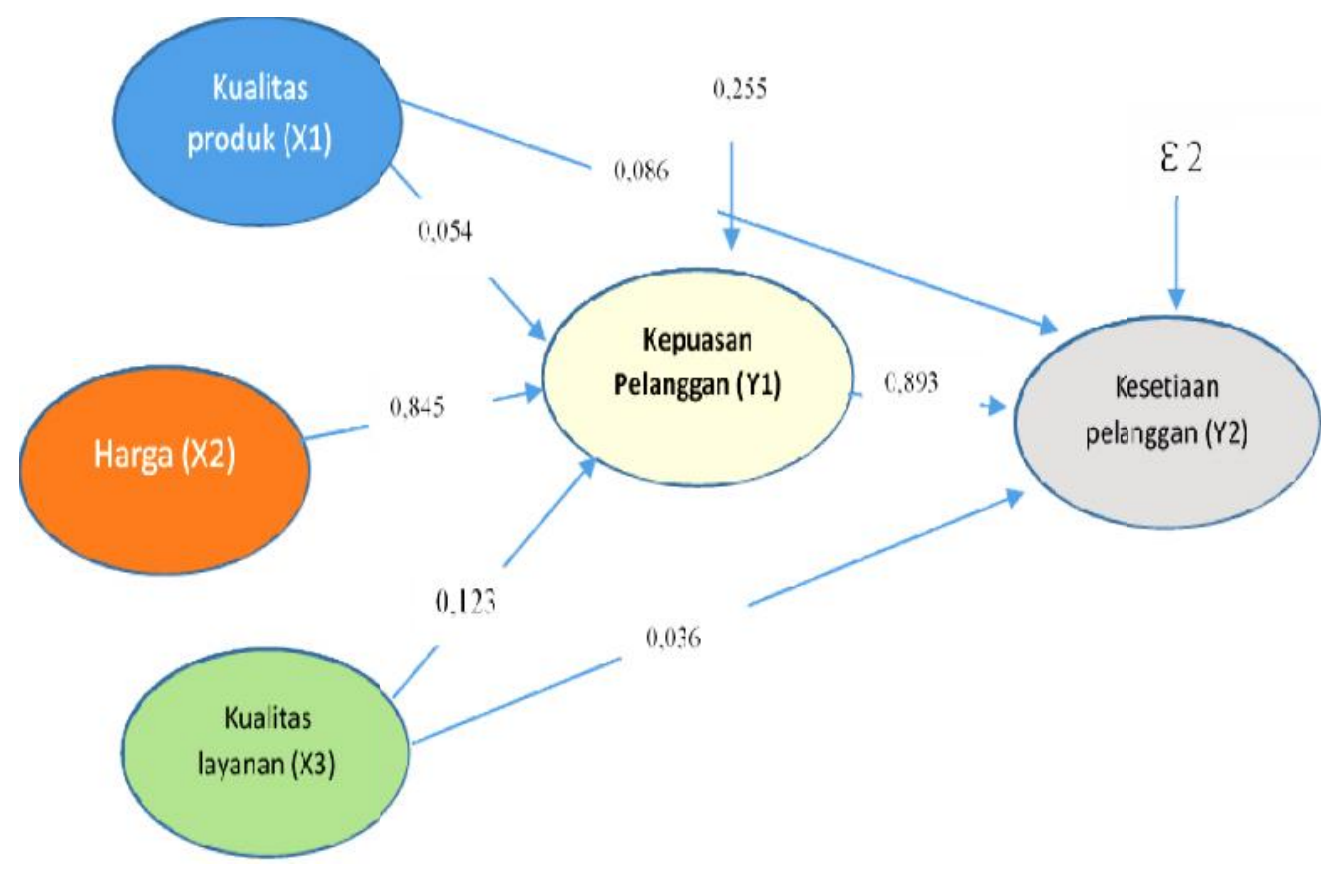

Gambar 2: Hasil Analisis Jalur 
Pengujian untuk semua hipotesis penelitian digunakan uji $\mathrm{t}$, bertujuan agar peneliti dapat mengetahui besar pengaruh dari variabel bebas yang ada terhadap vareabel terikat dan variabel moderating dengan memperhatikan nilai probabilitas kurang dari $(<0,05)$.

\section{Pengujian Hipotesis I : Pengaruh Kualitas Produk terhadap Kepuasan Pelanggan}

Kualitas Produk berpengaruh positif tetapi pengaruh tersebut tidak signiifikan terhadap kepuasan pelanggan yang berkunjung di destinasi wisata Wendit Kabupaten Malang. Pengaruh ini dilihat dari probabilitas yang ada $(>0,05)$ yaitu 0,190 . Kesimpulan hipotesis I pertama : secara statistik tidak bisa diterima atau tidak teruji. Tidak signifikannya variabel kualitas produk terhadap kepuasan pelanggan sangat wajar. Karena kaum milenial yang menjadi sampel penelitian lebih memilih tempat wisata yang istagramble dan kekinian sedangkan di wisata Wendit lebih mengedepankan wisata untuk keluarga seperti tempat pemandian dan konservasi hutan, selain itu berdasarkan pengalaman mayoritas responden mereka berkunjung bukan karena keinginan mereka tetapi lebih berdasarkan diajak teman dan keluarga. Hasil penelitian ini tidak sejalan dengan penelitian yang lakukan oleh Kurriwati (2012) bahwa kualitas produk berpengaruh positif dan signifikan terhadap kepuasan pelanggan.

\section{Pengujian Hipotesis II : Pengaruh Harga terhadap Kepuasan Pelanggan}

Melalui hasil uji $\mathrm{t}$ dapat diketahui bahwa variabel harga berpengaruh positif, pengaruh tersebut juga signifikan pada variabel kepuasan pelanggan berkunjung ke tempat wisata Wendit, ini dapat dilihat dari nilai probabilitas dibawah 0,050 yaitu 0,000 . Kesimpulan : hipotesis II (kedua) secara statistik dapat diterima.

Hasil yang ada sesuai pula dengan perilaku generasi millenial yang pada umumnya melihat biaya yang mereka keluarkan untuk suatu aktivitas harus sesuai dengan kemanfaatan yang dirasakan atau manfaat yang diinginkan (Hidayatullah, Waris, \& Devianti, 2018).

Kondisi pengamatan lapangan juga sudah terlihat baiaya masuk yang distandartkan oleh pengelola wisata Wendit dimana harga yang ditawarkan sudah sangat sesuai dengan segment masyarakat yang berkunjung, dimana tiket masuk : dewasa (Rp 15. 000) dan anak-anak ( $R p$ 10. 000), namun saat berada didalam tempat wisata apabila pengunjung akan menggunakan wahana diwajibkan membayar setiap wahana dimana biaya yang ada per wahana berkisar ( Rp 10 . 000 - Rp 25. 000).

Peneliti ini mendukung penelitian yang dilakukan oleh Setyowati (2017), bahwa variabel harga berpengaruh terhadap kepuasan pelanggan.

\section{Pengujian Hipotesis III : Pengaruh Kualitas Layanan terhadap Kepuasan Pelanggan}

Melalui hasil uji $\mathrm{t}$ diketahui bahwa dari Kualitas pelayanan berpengaruh yang positif, pengaruh tersebut juga signifikan terhadap kepuasan pelanggan dalam berkunjung ke tempat wisata Wendit, hasil ini terlihat dari nilai probalitas kualitas pelayanan yang masih berada dibawah 0,050 yaitu : 0, 008.

Kesimpulan dari hipotesis ketiga dapat diterima (teruji). Situasi ini disebabkan pengunjung sudah dapat menilai standart biaya tiket masuk murah yang dikeluarkan pengunjung ke wisata Wendit sudah sesuai dengan pelayanan yang diberikan oleh pengelola (Santos, 2003; Mardalis, 2005).

Standart pengelolaan tempat wisata sudah dipenuhi di tempat wisata Wendit seperti tempat parkir yang luas, jalan menuju dan dilokasi yang baik, adanya panggung hiburan serta tempat ibadah (mushola). Selain itu listrik, air bersih juga sudah terpenuhi diwisata Wendit. Penelitian ini juga mendukung penelitian yang dilakukan oleh Cahyani, (2016) yang menemukan bahwa kualitas layanan berpengaruh siginifikan dan positif terhadap kepuasan pelanggan. Artinya semakin besar kualitas pelayanan yang 
dihasilkan akan menambah besar kepuasan pelanggan yang ada.

\section{Pengujian Hipotesis IV : Pengaruh Kualitas Produk terhadap Kesetiaan Pelanggan}

Berdasarkan hasil uji t, diketahui bahwa variabel dari kualitas produk berpengaruh positif serta signifikan terhadap variabel Kesetiaan pelanggan dalam berkunjung ke tempat wisata Wendit, dilihat dari nilai probabilitas dibawah 0,05 yaitu sebesar 0 , 035. Kesimpulan hipotesis 4 (keempat) terbukti atau teruji secara statistiik. Sesuai dengan penelitian Pusparani \& Rastini, (2014) yang mengatakan kualitas dari produk berpengaruh langsung pada variabel kesetiaan pelanggan.

Teori yang dikemukakan Tjiptono \& Chandra, (2011) menyatakan kualitas dapat memberikan dorongan ke konsumen untuk membuat jalinan atau ikatan yang kuat pada perusahaan (tempat wisata). Sehingga menjaga kualitas dari produk serta inovasi produk yang up to date dapat menjembatani kesetiaan konsumen untuk berkunjung.

Penelitian ini juga mendukung penelitian yang dilakukan oleh Adare \& Lenzun, (2014) dimana kualitas produk berpengaruh signifikan terhadap kesetiaan pelanggan. Artinya, dengan peningktan kualitas produk yang ada di wisata Wendit akan membuat kesetiaan pelanggan bertambah (Hermawan, 2019), hal ini dikarenakan kualitas produk yang dihasilkan dalam hal ini wahana dan tempat wisata sangat berpengaruh terhadap kualitas produk yang dihasilkan dalam hal ini wahana dan tempat wisata sangat berpengaruh terhadap keinginan wisatawan untuk berkunjung kembali diwaktu yang akan datang.

\section{Pengujian Hipotesis V: Pengaruh Harga terhadap Kesetiaan Pelanggan}

Variabel harga berpengaruh positif namun pengaruh tersebut tidak signifikan terhadap kesetiaan pelanggan yang berkunjung di destinasi wisata Wendit Kabupaten Malang. Adapun nilai probabilitasnya variabel harga dibawah 0,050 yaitu 0,936 .
Penelitian ini sejalan dengan penelitian dari Pasaribu (2013) yang hasilnya variabel harga tidak berpengaruh signifikan terhadap variabel dari kesetiaan pelanggan, namun tidak mendukung penelitian dari Griffin, (2006) bahwa variabel harga signifikan terhadap kesetiaan dari pelanggan.

Hal ini berarti peran harga sangat berpengaruh terhadap kesetiaan pelanggan untuk berkunjung kembali ke tempat wisata Wendit selain itu kenyataan dilapangan memang untuk biaya atau harga tiket masuk di wisata Wendit sangat murah dan hal ini memungkinkan orang untuk berwisata secara kelompok besar dan keluarga dengan harapan wisata murah namun semua wahana dan kepuasan dapat terpenuhi.

\section{Pengujian Hipotesis VI : Pengaruh Kualitas Pelayanan terhadap Kesetiaan Pelanggan}

Variabel kualitas pelayanan berpengaruh positif tetapi tidak signifikan terhadap variabel Kesetiaan pelanggan yang berkunjung di destinasi wisata Wendit Kabupaten Malang. Adapun nilai probabilitas dari variabel kualitas pelayanan dibawah 0 , 050 yaitu sebesat 0,434 .

Penelitin ini tidak sejalan dengan penelitian yang dilakukan oleh Japarianto, Laksmono, \& Khomariyah, (2007) yang menunjukan bahwa kualitas layanan berpengaruh positif dan sinifikan. Hal ini berarti kualitas layanan dalam wahana Wendit sangat berpengaruh terhadap kesetiaan orang dalam berkunjung namun kepuasan tersebut tidak signifikan pengaruhnya terhadap niat wisatawan untuk berkunjung kembali ke wisata Wendit .

\section{Pengujian Hipotesis VII : Pengaruh Kepuasan Pelanggan terhadap Kesetiaan Pelanggan}

Kepuasan pelanggan berpengaruh positif serta signifikan terhadap kesetiaan pelanggan yang berkunjung di destinasi wisata Wendit Kabupaten Malang. Hal ini dapat dilihat dari nilai probabilitas yang berada dibawah $<0,05$ yaitu 0,000 . 
Kesimpulannya, jika pelanggan puas secara otomatis pelanggan tersebut akan setia kepada tempat wisata Wendit . Kepuasan pada pelanggan bisa menjembatani terwujudnya militansi pelanggan. Penelitian ini mendukung penelitian yang dilakukan oleh Harnoto, (2014) bahwa kepuasan pelanggan berpengaruh signifikan terhadap kesetiaan pelanggan.

Hal ini berarti pelanggan yang puas secara otomatis akan membuat rasa ingin berkunjung kembali ke tempat wisata Wendit dan bila ini terjadi maka kesetiaan pelanggan akan terwujud. Penelitian ini juga mendukung penelitian sebelumnya yang dilakukan oleh Hermawan, (2017) yang menemukan bahwa kepuasan berpengaruh signifikan terhadap loyalitas pengunjung.

Selain itu, hubungan diantara kedua variabel penelitian tersebut adalah positif, maka semakin meningkatnya kepuasan pengunjung akan semakin meningkat pula loyalitasnya, sebaliknya semakin menurun kepuasan pengunjung akan berdampak terhadap semakin menurunnya loyalitas pengunjung.

Penemuan ini telah sesuai teori loyalitas pelanggan dalam buku-buku pemasaran pada umumnya. Sehingga, penelitian verifikatif yang telah dilakukan berhasil memverivikasi teori loyalitas secara umum. Artikel ini sekaligus menegaskan sebuah model teori pelayanan serta hubunganya dengan kepuasan dan loyalitas, sekaligus mampu meminimalisir adanya kemungkinan loyalitas semu sehingga model ini dapat dipakai dalam implementasi manajemen pelayanan

\section{Pengujian Hipotesis VIII : Pengaruh Kualitas Produk terhadap Kesetiaan Pelanggan melalui Kepuasan Pelanggan}

Kepuasan pelanggan sebagai variabel moderating antara kualitas produk dan kesetiaan pelangggan total effect nya lebih besar dari direct effect $(0,947>0,086)$ dari variable kualitas produk ke kesetiaan pelannggan.

Kesimpulannya, meningkatnya harga akan berimbas pada kepuasan konsumen yang juga dapat diikuti dengan peningkatan kesetiaan dari pelanggan.

Konsep dari kualitas suatu produk merupakan suatu faktor dominan pada keberhasilan suatu perusahaan hal ini disebabkan bila pelanggan merasakan suatu kualitas produk yang diterimanya atau dirasakannya sudah baik sesuai dengan harapan, sehingga kepuasan dari pelangan akan secara otomatis mengikuti. Hasil penelitian ini sejalan dengan penelitian yang dilakukan oleh Irawan \& Japarianto (2013) yang mengatakan kualitas produk bepengaruh terhadap loyalitas pelanggan melalui kepuasan pelanggan

Hal ini berarti variabel kepuasan yang memediasi juga sangat berpengaruh terhadap pelanggan menjadi loyal, selain hal tersebut dilihat dari total effek yang ada pengaruh yang diberikan kepuasan pelanggan sangat besar sehingga keberadaan kepuasan untuk membuat orang mau dan berminat untuk berkunjung kembali juga sangat besar.

\section{Pengujian Hipotesis IX : Pengaruh Harga terhadap Kesetiaan Pelanggan melalui Kepuasan Pelanggan}

Kepuasan pelanggan sebagai variabel moderating antara harga ke kesetiaan dari pelangggan dilihat dari total effect dengan direct effect $(1,739>-0.009)$ yang ada dari kualitas produk ke variabel kesetiaan pelanggan terhadap variabel dari harga. Kesimpulan, harga yang meningkat akan dapat meningkatkan kepuasan konsumen jika diikuti dengan perbaikan fasilitas dan pelayanan yang ada sehingga kesetiaan pelangganjuga akan dapat meningkat (Kusdyah, 2012; Setyowati, 2017).

\section{Pengujian Hipotesis $\mathrm{X}$ : Pengaruh Kualitas Pelayanan terhadap Kesetiaan Pelanggan melalui Kepuasan Pelanggan}

Kepuasan pelanggan yang merupakan variabel moderating yang menghubungkan kualitas pelayanan dengan kesetiaan pelangggan dilihat dari nilai indirect effect $(0,109)$ dan direct effect $(0,036)$. Dilihat dari pengaruh tidak langsung lebih besar dari 
pengaruh langsung artinya terdapat pengarug signifikan.

Kesimpulan dengan kualitas pelayanan yang meningkat dapat meningkatkan kepuasan konsumen yang pada akhirnya secara otomatis juga dapat meningkatkan variabel kesetiaan dari pelanggan. Untuk meningkatkan kualitas layanan yang ada diperlukan sistem marketing yang efektif dalam pemasaran usaha wisata (Hidayatullah, Rachmawati, \& Khouroh, 2017), hal ini diharpakan memasuki dunia kaum millennial yang sudah tidak lepas dari informasi yang instan dan online.

Hasil riset juga mendukung penelitian yang dilakukan oleh Sembiring; \& Kusumawati Andriani (2014) bahwa kualitas pelayanan dan kepuasan berpengaruh signifikan terhadap kesetiaan pelanggan, artinya dengan adanya kualitas yang baik akan meningkatkan kesetiaan pengunjung untuk datang kembali ke Wisata Wendit melalui kepuasan yang ada.

\section{Analisis Jalur}

Dari hasil analisis jalur yang ada diketahui bahwa kualitas produk tidak berpengaruh signifikan terhadap kepuasan pelanggan hal ini dapat terjadi karena rata-rata pengunjung yang ada ke Taman Wisata Wendit sudah paham apa yang diperoleh mereka jika datang kesana, artinya mereka sudah paham dan tidak mengharapkan sesuatu yang lebih kecuali jika ada informasi dibukanya wahana baru.

Selanjutnya harga dan kualitas pelayanan berpengaruh terhadap kepuasan pelanggan hal ini sangat linear dengan kondisi yang ada di Taman Wisata Wendit diaman taman wisata ini masih bertahan dan menempatkan dirinya sebagai tempat wisata murah tanpa mengurangi kualitas pelayanan yang baik ke pelanggaran atau wisatawan yang datang.

Temuan penting dalam penelitian ini adalah secara langsung harga dan kualitas pelayanan tidak berpengaruh terhadap kesetiaan pelanggan namun jika dilihat secara tidal langsung harga dan kualitas berpengaruh terhadap kesetiaan pelanggan melalui kepuasan pelanggan, dan pengaruh total yang adapun sangat besar.

Implementasi hasil kajian ini, perlu diketahui bahwa sepanjang 2019, Kabupaten Malang membidik lebih dari tujuh juta wisatawan lokal maupun mancanegara untuk berkunjung ke kabupaten berjuluk "Seribu Pantai". Target itu dinilai cukup realistis karena pada tahun lalu arus kunjungan wisatawan ke wilayah itu mencapai 6,5 juta orang.

Promosi wisata melalui berbagai even dan pameran wisata, serta mengembangkan objek wisata potensial. Seperti program dan mengikuti pameran wisata di berbagai daerah hingga luar negeri, objek wisata di Kabupaten Malang semakin dikenal dan menjadi daerah tujuan wisata bagi wisatawan domestik maupun mancanegara.

Selain promosi, untuk mengenalkan berbagai objek wisata di Kabupaten Malang, pihaknya juga mengintensifkan dan mengoptimalkan keberadaan Kelompok Sadar Wisata (Pokdarwis). Keberadaan Pokdarwis tersebut, selain bertugas mengenalkan objek-ojek wisata, juga memobilisasi wisatawan dari berbagai daerah, bahkan untuk saling berkunjung ke daerah wisata masing-maisng.

Dari sejumlah lokasi wisata di Kabupaten Malang, sebagian besar berupa wisata alam pantai, seperti: Pantai Kondang Merak, Balekambang, Sendangbiru, Ungapan, Ngudel, Licin, Goa China, Pantai Tiga Warna, Banyu Anjlok, Bangkung, Bajul Mati dan Ngliyep.

Selain pantai, peninggalan sejarah berupa candi juga cukup banyak di Kabupaten Malang, seperti Candi Singosari, Candi Kidal, dan Candi Jago. Sementara wisata buatan yang masih menjadi "legenda" adalah Taman Wisata Wendit yang dikenal dengan banyaknya kera di area tersebut.

Untuk meningkatkan jumlah kunjungan wisata Wendit berbagai upaya dapat dilakukan oleh Pemerintah Daerah dan Pengelola. Pengelola perlu mempertahankan sesuatu yang sudah dirasa cukup baik dan masih ada yang perlu diperbaiki untuk 
pengembangan Wisata Wendit. Hal ini terlihat dari hasil penelitian yang tertuang dalam open kuesioner yang responden mengatakan perlunya perbaikan dan update wahana yang khususnya bersentuhan dengan generasi milenial dimana usia milenial sangat membutuhkan sesuatu yang baru untuk dikunjungi.

Ada beberapa hal yang perlu diperhatikan dalam usaha untuk meningkatkan kunjungan wisatawan seperti: (1) Promosi terus menerus, Promosi wajib dilakukan agar turis asing semakin mengenal daerah tujuan wisata. Baik itu dengan ikut pameran internasional dan juga melalui website. Apalagi sekarang didukung oleh kemajuan teknologi komunikasi, proses promosi bisa dilakukan dengan mudah, murah dan menjangkau daerah yang lebih luas; (2)Meningkatkan kualitas layanan dan akomodari pariwisata, Pelayanan yang baik nan ramah akan membuat turis menjadi senang dan bukan tidak mungkin mereka akan datang berkunjung lagi. Inilah yang diharapkan. Jika kesan yang menempel dipikirannya bagus, mereka pasti ingin melakukan kunjungan kembali ke tempat wisata tersebut; (3) Meningkatkan Keamanan : Aman membuat mereka tidak khawatir ketika bepergian kesana kemari, tanpa takut diganggu orang jahat yang hanya ingin mendapatkan keuntungan materi. Keamanan meningkat jika ada peran aktif para penegak hukum menjaga wilayahnya dari sentuhan orang-orang yang tidak bertanggung jawab. Masyarakat setempat juga harus ikut menjaga suasana yang aman agar wisatawan bisa menikmati liburan dengan nyaman. Selain itu keramahtamahan warga juga sangat menentukan kemajuan pariwisata suatu daerah; (4) Promo Paket wisata : Potongan harga besar bisa membuat mereka bergegas untuk mengambil keputusan dan akhirnya mengambil paket tersebut; (5) Memperbanyak destinasi wisata : Pengunjung terutama usia millennial biasanya tertarik dengan tempat wisata baru, unik dan menarik. Hal tersebut dapat diwujudkan dengan membuat destinasi baru yang belum ada. (Li, Hu, Huang, \& Duan,
2017) Selain itu juga perlu adanya pihak lain atau pihak ketiga dalam hal ini seperti pemerintah (Windhyastiti \& Widiawati, 2016) dan investor untuk memberikan sentuhan lebih terhadap keberadaan Taman Wisata Wendit sehingga adanya dan terus adanya update wahana yang kekinian dan milenial. Apa dan bagaimana menarik investor tentu harus dipahami bagaimana serta apa yang harus dilakukan pihak pengelola dan investor (Windhyastiti, Hidayatullah, \& Khouroh, 2019) sebelum berinvestasi khususnya bidang wisata .

Dari pembahasan dan diskusi di atas hasil temuan mengarahkan untuk merekomendasikan agar destinasi wisata Wendit hendaknya meningkatkan kualitas produk, harga dan kualitas layanan untuk meningkatkan kesetiaan pelanggan melalui kepuasan pelanggan. Hal ini juga merekomendasikan kepada destinasi wisata Wendit untuk meneningkatakan layanan dan informasi kepada pelanggan guna meningkatkan kepuasan dan kepercayaan dan loyalitas pelanggannya. Kepercayaan yang ada pada pelanggan akan membuat pelanggan mengambil keputusan untuk berkunjung kembali membuat keputusan menentukan pembelian suatu produk atau jasa (Rakhmadian, Hidayatullah, Respati, \& Malang, 2017).

\section{SIMPULAN}

Kualitas dari produk tidak secara langsung berpengaruh ke kepuasan pelannggan wisata Wendit, artinya bila produk meningkat yang meningkat tidak secara otomatis meningkatkan kepuasan pelanggan,

Harga secara langsung berpengaruh terhadap kepuasan dari pelanggan wisata Wendit, artinya peningkatan harga tidak secara langsung meningkatkan kepuasan pelanggan,

Kualitas layanan secara langsung berpengaruh pada kepuasan dari pelanggan wisata Wendit, artinya meningkatkan kualitas layanan akan meningkatkan pula kepuasan pelanggan, 
Kualitas dari produk secara langsung berpengaruh pada kesetiaan dari pelanggan wisata Wendit, artinya jika kualitas produk ditingkatkan maka akan meningkatkan pula kesetiaan pelanggan,

Harga secara langsung tidak berpengaruh pada kesetiaan pelanggan wisata Wendit, artinya peningkatan harga tidak secara otomatis meningkatkan peningkatan kesetiaan dari pelanggan,

Kualitas layanan secara langsung tidak berpengaruh terhadap kesetiaan pelanggan wisata Wendit, artinya jika kualitas layanan meningkat maka tidak meningkatkan kesetiaan pelanggan,

Kualitas produk secara tidak langsung berpengaruh terhadap kesetiaan dari pelanggan tempat wisata Wendit melalui kepuasan pelannggan, artinya jika kualitas produk ditingkatkan maka kesetiaan dari pelanggan wisata Wendit akan meningkat pula dengan perantara kepuasan pelanggan.

Situasi yang kompetitif dalam dunia usaha memang sangat ketat sehingga membutuhkan inovasi-inovasi dan jiwa entrepreneur marketing yang matang sehingga bisa memenangkan persaingan (Hidayatullah, Firdiansjah, Patalo, \& Waris, 2019).

Selain hal tersebut, tampilan website yang ada pada tempat wisata Wendit juga perlu pembenahan yang lebih menarik, karena website yang menarik dan kekinian dapat memikat orang untuk terus berkunjung dan senang berlama-lama untuk mencari informasi (Stephanie, Hidayatullah, \& Ardianto, 2019).

\section{REFERENSI}

Adare, D., \& Lenzun, J. (2014). Pengaruh Kualitas Produk, Harga Dan Promosi Terhadap Kepuasan Pelanggan Kartu Prabayar Telkomsel. Jurnal Riset Ekonomi, Manajemen, Bisnis Dan Akuntansi. 2(3): 24-30

Alvianna, S. (2017). Analisis Pengaruh Harga, Produk, Dan Kualitas Layanan
Terhadap Kepuasan Wisatawan Di Taman Wisata Air Wendit Kabupaten Malang. Jurnal Pariwisata Pesona,2(1):1-12. https://doi.org/10.26 905/jpp.v2i1.1263.

Aryani, D., \& Rosinta, F. (2010). Pengaruh Kualitas Layanan terhadap Kepuasan Pelanggan dalam Membentuk Loyalitas Pelanggan. Jurnal Ilmu Administrasi Dan Organisasi. 17(2): 114-126

Cahyani, F. G. (2016). Pengaruh Kualitas Produk, Kualitas Pelayanan, Dan Harga Terhadap Kepuasan Konsumen. Jurnal Ilmu Dan Riset Manajemen, 5 (3): 1-9

Damasdino, F. (2015). Studi Karakteristik Wisatawan dan Upaya Pengembangan Produk Wisata Tematik di Pantai Goa Cemara, Pantai Kuwaru, dan Pantai Pandansimo Baru Kabupaten Bantul. Media Wisata,12(2): 308-320

Griffin, R. (2006). Customer Loyalty: Menumbuhkan dan Mempertahankan Kesetiaan Pelanggan. In MIT Press Books. Pages 228-235

Harnoto, F. (2014). Strategi Kepuasan Pelanggan Dalam Mempertahankan Dan Meningkatkan Loyalitas Pelanggan. Jurnal Ekonomi Manajemen Dan Akuntansi. 12(2):308320

Hasan, S., \& Putra, A. H. P. K. (2019). Loyalitas Pasien Rumah Sakit Pemerintah: Ditinjau dari Perspektif Kualitas Layanan, Citra, Nilai dan Kepuasan. Jurnal Manajemen Indonesia, 18(3):184-196. https://doi.org/10.25124/jmi.v18i3.173 1

Hermawan, H. (2016). Dampak Pengembangan Desa Wisata Nglanggeran Terhadap Ekonomi Masyarakat Lokal. Jurnal Pariwisata, $3(2): 105-117$ 
Hermawan, H. (2017). Pengaruh Daya Tarik Wisata, Keselamatan dan Sarana Wisata Terhadap Kepuasan serta Dampaknya terhadap Loyalitas Wisatawan: Studi Community Based Tourism di Gunung Api Purba Nglanggeran. Jurnal Media Wisata, 15(1): 562-577

Hermawan, H., Wijayanti, A., \& Nugroho, D. S. (2019). Loyalty on Ecotourism analysed using the factors of tourist attraction, safety, and amenities, with satisfaction as an intervening variable. African Journal of Hospitality, Tourism and Leisure, 8(5):1-19. https://ajhtl.com,

Hidayatullah, S., Firdiansjah, A., Patalo, R. G., \& Waris, A. (2019). The effect of entrepreneurial marketing and competitive advantage on marketing performance. International Journal of Scientific and Technology Research. 8(1): 297-1301

Hidayatullah, S., Rachmawati, I. K., Aristanto, E., Waris, A., \& Patalo, R. G. (2020). Peran Sistem Informasi Pemasaran, Kualitas Pelayanan dan Entrepreneurial marketing serta Kepuasan Terhadap Loyalitas Generasi Milenial Berkunjung ke Tempat Wisata. https://doi.org/10.32812/jibeka.v14i1.1 48. hal 74-83

Hidayatullah, S., Rachmawati, I. K., \& Khouroh, U. (2017). The Effectivity of Pokdarwis: Role on Successfully Marketing of Tourism Village Towards Mega Tourism : Batu City For The World . August, 978-979.

Hidayatullah, S., Waris, A., \& Devianti, R. C. (2018). Perilaku Generasi Milenial dalam Menggunakan Aplikasi GoFood. Jurnal Manajemen Dan Kewirausahaan, hal 240-249. https://doi.org/10.26905/jmdk.v6i2.256 0

Irawan, D., \& Japarianto, E. (2013). Analisa Pengaruh Kualitas Produk Terhadap Loyalitas Melalui Kepuasan Sebagai Variabel Intervening Pada Pelanggan Restoran Por Kee Surabaya. Jurnal Manajemen Pemasaran, 1(2): 1-8

Japarianto, E., Laksmono, P., \& Khomariyah, N. A. (2007). Analisa Kualitas Layanan Sebagai Pengukur Loyalitas Pelanggan Hotel Majapahit Surabaya Dengan Pemasaran Relasional Sebagai Variabel Intervening. Jurnal Manajemen Perhotelan. https://doi.org/10.9744/jmp.3.1.34-42

Kotler, P. (2012). Marketing management /Philip Kotler, Kevin Lane Keller. In Marketing management. 234-256

Kurriwati, N. (2012). Pengaruh Kualitas Produk Terhadap Kupuasan dan Dampaknya Terhadap Loyalitas Konsumen. Jurnal Manajemen Pemasaran Petra, 1(1): 48-55

Kusdyah, I. (2012). Persepsi Harga, Persepsi Merek, Persepsi Nilai, dan Keinginan Pembelian Ulang jasa Klinik Kesehatan. Jurnal Manajemen Pemasaran. https://doi.org/10.9744/pemasaran.7.4.

Li, Y., Hu, C., Huang, C., \& Duan, L. (201 7). The concept of smart tourism in the context of tourism information services. Tourism Management. https://doi.org/10.1016/j.tourman.2016. 03.014

Mardalis, A. (2005). Meraih Loyalitas Pelanggan. Benefit: Jurnal Manajemen Dan Bisnis, 8(5) 111-119

Nurhasan, R. (2017). Kepuasan Kerja dan Loyalitas Generasi Y. Jurnal Wacana Ekonomi, 17(1):1-11 
Pusparani, P., \& Rastini, N. (2014). Pengaruh Kualitas Produk Dan Brand Image Terhadap Kepuasan Konsumen Dan Loyalitas Pelanggan Kamera Canon Digital Single Lens Reflex (DSLR) Di Kota Denpasar. E-Jurnal Manajemen Universitas Udayana, 17(1): 1-11

Rakhmadian, M., Hidayatullah, S., Respati, H., \& Malang, U. M. (2017). Analisis Kualitas Sistem Dan Kualitas Informasi Terhadap Kepuasan Pemakai Sistem Informasi Akademik Dosen. Seminar Nasional Sistem Informasi, September, 665-675.

Santos, J. (2003). E-service quality: A model of virtual service quality dimensions. Managing Service Quality: An International Journal. https://doi.org/10.1108/096045203104 76490.

Sembiring;, S. I. J., \& Kusumawati Andriani. (2014). Kepuasan Pelanggan Dalam Membentuk Loyalitas Pelanggan ( Studi pada Pelanggan McDonald 's MT . Haryono Malang ). Jurnal Administrasi Bisnis (JAB), 17(2): 114126

Setyowati, E. (2017). Pengaruh Kualitas Pelayanan, Harga, Dan Citra Merek Terhadap Loyalitas Pelanggan Dengan Kepuasan Pelanggan Sebagai Variabel Pemediasi. Jurnal Manajemen Dayasaing. https://doi.org/10.23917/dayasaing.v18 i2.4507.

Stephanie, A., Hidayatullah, S., \& Ardianto, Y. T. (2019). An Emperical Study of Website Quality on Hotel Booking Online. 4(2): 10-14.

Sugiyono. (2014). Metode penelitian.

Bandung: Alfabeta

Tjiptono, F., \& Chandra, G. (2011). Service,
Quality \& Satisfaction. In Edisi 4. https://doi.org/10.3389/fgene.2015.002 93

Windhyastiti, I., Hidayatullah, S., \& Khouroh, U. (2019). How to increase city investment attraction. International Journal of Scientific and Technology Research, 8(9): 1070-1073

Windhyastiti, I., \& Widiawati, D. (2016). Pentingnya Aspek Goverment Power Dalam Pengembangan Industri Pariwisata Daerah. Jurnal Manajemen dan Kewirausahaan. https://doi.org/10.26905/jmdk.v4i1.405

Yuswohady. (2016). Millennial Trends 2016. https://www.yuswohady.com/2016/01/ 17/millennial-trends-2016/. dikutip 12 Februari 2020

\section{PROFIL PENULIS}

Stella Alvianna, penulis merupakan dosen tetap Program Studi Diploma Kepariwisataan Universitas Merdeka, Malang, Indonesia. Id Scholar https://scholar.google.co.id/citations?hl=id\& user=svZYQFoAAAAJ

Syarif Hidayatullah, penulis merupakan dosen tetap Program Studi Diploma Kepariwisataan Universitas Merdeka, Malang, Indonesia. 